\title{
Pendidikan Ibu Berbasis Masyarakat (PIBM) dalam Meningkatkan Pengetahuan dan Sikap Pemenuhan Gizi Balita Stunting
}

\author{
Titih Huriah $^{1 *}$, Yunita Larasati², Tiwi Sudyasih ${ }^{3}$, Sutantri², Bambang Edi Susyanto ${ }^{4}$ \\ ${ }^{1}$ Magister Keperawatan UMY, Jalan Brawijaya, Kasihan, Bantul, Yogyakarta, 55183 \\ ${ }^{2}$ Program Studi Ilmu Keperawatan UMY, Jalan Brawijaya, Kasihan, Bantul, Yogyakarta, 55183 \\ ${ }^{3}$ Program Studi Ilmu Keperawatan Universitas ‘Aisyiyah, Jalan Siliwangi, Sleman, Yogyakarta, 55292 \\ ${ }^{4}$ Fakultas Kedokteran dan Ilmu Kesehatan UMY, Jalan Brawijaya, Kasihan, Bantul, Yogyakarta, 55183 \\ *Email Korespondensi: titih.huriah@umy.ac.id
}

\begin{abstract}
Abstrak
Stunting merupakan salah satu bentuk malnutrisi pada anak, sebanyak 156 juta anak di dunia terkena stunting. Prevalensi balita yang mengalami kejadian sangat pendek di DIY sebesar 8,3\%, sedangkan prevalensi balita yang mengalami kejadian pendek sebesar 12,2 \%. Kelurahan Bumijo merupakan salahsatu Kelurahan di Kecamatan Jetis dengan angka prevalensi stunting paling tinggi. Stunting merupakan masalah kesehatan yang dapat dicegah dengan memberdayakan masyarakat, khususnya ibu untuk diberikan pendidikan kesehatan mengenai pentingnya gizi bagi anak balita. Perilaku gizi ibu yang baik dapat memberikan dampak positif pada nutrisi balita. Tujuan kegiatan pengabdian masyarakat ini adalah untuk meningkatkan pengetahuan dan sikap ibu dalam memenuhi kebutuhan gizi balita stunting di Kota Yogyakarta. Kegiatan pengembangan model pendidikan ibu berbasis masyarakat dalam pencegahan stunting di fokuskan di RW 09 Bumijo sebagai RW percontohan dan merupakan RW dengan prevalensi stunting tertinggi. Kegiatan pengabdian masyarakat dilaksanakan selama 2 bulan yaitu dari Bulan Januari sampai dengan Februari 2020, dimana dilaksanakan pertemuan rutin dengan kelompok ibu balita setiap 1 minggu sekali sehingga total kegiatan pendampingan adalah 5 kali pertemuan. Hasil pengabdian masyarakat memperlihatkan tidak terjadi peningkatan pengetahuan namun terjadi peningkatan sikap ibu dalam pemenuhan gizi pada balita dengan p value 0,001. PIBM diharapkan menjadi salahsatu program dalam penanganan masalah stunting pada balita.
\end{abstract}

Kata kunci: Pendidikan ibu berbasis masyarakat; stunting; balita; perilaku ibu

\begin{abstract}
Stunting is a form of malnutrition in children. As many as 156 million children in the world affected by stunting. The prevalence of children under five who experienced severe stunting and stunting in Yogyakarta province was $8.3 \%$ and $12.2 \%$ respectively. Bumijo Village is one of the villages in Jetis District with the highest stunting prevalence rate. Stunting is a health problem that can be prevented by empowering the community, such as by giving health education to the mothers about the importance of nutrition for children under five. Good nutritional behaviour of mothers can have a positive impact on toddler nutrition. The purpose of this community service activity was to increase the knowledge and attitudes of mothers in meeting the nutritional needs of stunting toddlers in the city of Yogyakarta. The activity of developing a community-based maternal education model in stunting prevention is focused on RW 09 Bumijo as a pilot RW and is the RW with the highest stunting prevalence. Community service activities were carried out for 2 months, from January to February 2020, where regular meetings were held with the groups of mothers of children under five every week so there was a total of 5 meetings. The results of community service showed no increase in knowledge but an increase in the attitude of mothers in fulfilling nutrition of children under five with a $p$ value of 0.001. PIBM is expected to be one of the programs in handling stunting problems in children under five.
\end{abstract}

Keywords: Community-Based Mother Education; stunting; children under five; maternal behaviour

Format Sitasi: Huriah, T., Larasati, Y., Sudyasih, T., Sutantri, Susyanto, B.E. Pendidikan Ibu Berbasis Masyarakat (PIBM) dalam Meningkatkan Pengetahuan dan Sikap Pemenuhan Gizi Balita Stunting. Jurnal Solma, 09(2), 400-410. Doi: http://dx.doi.org/10.22236/solma.v9i2.4930

Diterima: 19 April 2020 | Revisi 04 September 2020 | Dipublikasikan: 30 Oktober 2020


(C) 2020 Oleh authors. Lisensi Jurnal Solma, LPPM-Uhamka, Jakarta. Artikel ini bersifat open access yang didistribusikan di bawah syarat dan ketentuan Creative Commons Attribution (CC BY) license. (http://creativecommons.org/licenses/by/4.0/).

\section{PENDAHULUAN}

Masalah kesehatan yang umum ditemukan pada balita khususnya pada negara berkembang yaitu malnutrisi. Angka morbiditas dan mortalitas akan meningkat pada anak yang mengalami malnutrisi. Secara tidak langsung, malnutrisi dapat mengakibatkan kematian setiap tahun sebanyak 60\% pada anak di bawah usia lima tahun (Sahanggamu et al., 2017). Stunting merupakan salah satu bentuk malnutrisi pada anak, sebanyak 156 juta anak dalam skala dunia terkena stunting (Chuc et al., 2019).

Kejadian stunting di Indonesia prosentasenya sekitar 37\% (Beal et al., 2018). Sebuah studi di Indonesia melaporkan prosentase balita dengan stunting sebesar 7,2\% (Minh Do et al., 2018). Angka kejadian stunting di Kota Yogyakarta sebesar 14,32\%, dan Kabupaten Sleman sebesar 12,87\% yang tersebar di tiga Kecamatan dengan angka kejadian paling tinggi yaitu Kecamatan Minggir sebesar 1,67\%, yang kedua adalah Kecamatan Ngemplak sebesar 1,44\%, dan ke-tiga adalah Kecamatan Moyudan sebesar 1,43\% (Ngaisyah, 2017). Kelurahan Bumijo merupakan salahsatu Kelurahan di Kecamatan Jetis dengan angka prevalensi stunting paling tinggi dimana pada Tahun 2019, teridentifikasi 42 balita balita stunting.

Stunting merupakan penanda risiko pertumbuhan balita yang buruk (Batiro, 2017). Stunting adalah keadaan tubuh balita yang memiliki tinggi badan yang lebih rendah dari standar pertumbuhan badan balita pada seumurannya, dimana tinggi badan melampaui defisit 2 standar deviasi (SD) dibawah median panjang atau tinggi badan populasi yang menjadi referensi internasional (Kemenkes RI, 2019; Beal et al., 2018; Dewi \& Aminah, 2016; Rahmawati et al., 2018; Saputri, 2018). Stunting adalah suatu kondisi dimana panjang badan atau tinggi badan tidak sesuai dengan usia akibat pemenuhan nutrisi yang tidak tercukupi sehingga balita mengalami kegagalan untuk tumbuh tinggi dan berkembang secara optimal dalam kurun waktu yang lama (Torlesse et al., 2016; Lusita \& Rahfiludin, 2017; Rabaoarisoa et al., 2017; Rahmawati et al., 2018). Kebutuhan zat gizi yang optimal untuk perkembangan dan pertumbuhan perlu diperhatikan karena balita rentan terhadap kelainan gizi (Pratiwi et al., 2016).

Stunting merupakan masalah kesehatan yang dapat dicegah dengan memberdayakan masyarakat, khususnya ibu untuk diberikan pendidikan kesehatan mengenai pentingnya gizi bagi anak balita. Pendidikan kesehatan dengan metode tertentu dapat mempengaruhi perbedaan pengetahuan, sikap, dan tindakan setelah diberikan edukasi yang cukup baik. Edukasi yang diberikan tidak hanya mengenai pencegahan, tetapi juga ditujukan kepada ibu untuk mempersiapkan pertumbuhan dan perkembangan anak sejak dini (Andriani et al., 2017).

Pengetahuan tentang kesehatan dan gizi yang dimiliki ibu akan sangat mempengaruhi status gizi anak balita (Sahanggamu et al., 2017). Perilaku gizi ibu yang baik dapat memberikan dampak positif pada nutrisi balita. Kemampuan ibu dalam menyediakan bahan makanan dan menu yang tepat didukung dengan pengetahuan yang dimiliki mengenai nutrisi dapat mencegah masalah nutrisi pada balita (Pratiwi et al., 2016). Ibu dengan tingkat 
pendidikan yang tinggi mempengaruhi pola asuh anak, termasuk dalam pemberian makan, pola konsumsi pangan, dan status gizi (Kusumaningrum \& Pudjirahaju, 2018).

Beberapa penelitian yang dilakukan sebelumnya yaitu "Upaya Promotif untuk Meningkatkan Pengetahuan Ibu Balita tentang Pencegahan Stunting dengan Media Integrating Card di Kecamatan Jatinangor Kabupaten Sumedang” oleh Astuti \& Megawati (2018) menyatakan terdapat peningkatan perilaku gizi ibu melalui pemberian pendidikan kesehatan dan memiliki pengaruh cukup besar terhadap kemampuan dan kesiapan ibu terhadap pemenuhan nutrisi pada balita untuk mencegah stunting. Pendidikan ibu yang tinggi mempengaruhi kognitif dan afektif ibu tentang kesadaran terhadap upaya perbaikan gizi. Berdasarkan latar belakang yang telah dipaparkan, maka tujuan kegiatan pengabdian masyarakat adalah untuk meningkatkan pengetahuan dan perilaku ibu dalam memenuhi kebutuhan gizi balita stunting di Kota Yogyakarta.

\section{MASALAH}

Angka kejadian stunting di Kota Yogyakarta sebesar 14,32\% (Ngaisyah, 2017). Kelurahan Bumijo merupakan salah satu Kelurahan di Kecamatan Jetis dengan angka prevalensi stunting paling tinggi dimana pada Tahun 2019, teridentifikasi 42 balita balita stunting. Stunting merupakan masalah kesehatan yang dapat dicegah dengan memberdayakan masyarakat, khususnya ibu untuk diberikan pendidikan kesehatan mengenai pentingnya gizi bagi anak balita. Pendidikan kesehatan dengan metode tertentu dapat mempengaruhi perbedaan pengetahuan setelah diberikan edukasi yang cukup baik. Edukasi yang diberikan tidak hanya mengenai pencegahan, tetapi juga ditujukan kepada ibu untuk mempersiapkan pertumbuhan dan perkembangan anak sejak dini.

Berdasarkan permasalahan tersebut, pendidikan kesehatan terkait gizi yang tepat untuk balita stunting sangat diperlukan agar tidak terjadi dampak yang lebih berat dari kondisi stunting yang dialami oleh anak. Ibu dapat memberikan makanan yang bergizi sehingga masalah stunting pada anak balita dapat diatasi.

\section{METODE PELAKSANAAN}

Prosedur pengembangan model pendidikan ibu berbasis masyarakat melalui beberapa tahap mulai dari tahap persiapan, edukasi dan latihan, koordinasi intersektoral sampai dengan fase akhir yaitu fase evaluasi. Pelaksanaan setiap fase dapat dilihat pada Tabel 1.

Tabel 1. Tahapan Kegiatan Pengabdian Masyarakat

Tahapan

Kegiatan
Bentuk Kegiatan

Pada fase persiapan, tim akan memilih area, cara kontak, mempelajari masyarakat dan melakukan perizinan. Tim pengabdian juga mempersiapkan modul edukasi gizi. Pada tahap ini juga, tim melakukan skrining status gizi balita dengan menggunakan indeks antropometri $\mathrm{TB} / \mathrm{U}$ atau $\mathrm{PB} / \mathrm{U}$ untuk melihat status gizi stunting dan resiko stunting pada balita di Bumijo. Kegiatan skrining dilakukan pada saat kegiatan Posyandu balita. Setelah Terskrining 15 orang balita, maka tim 


\begin{tabular}{|c|c|}
\hline & $\begin{array}{l}\text { memberikan informed consent ke ibu balita yang akan mengikuti } \\
\text { kegiatan PIBM. }\end{array}$ \\
\hline $\begin{array}{l}\text { Edukasi } \\
\text { latihan }\end{array}$ & $\begin{array}{l}\text { Pada tahap edukasi dan latihan, tim pengabdian masyarakat melakukan } \\
\text { edukasi seminggu sekali selama } 5 \text { minggu dengan materi-materi yang } \\
\text { berbeda terkait stunting dan perilaku pemenuhan gizi pada balita } \\
\text { stunting. Setiap Ibu yang mempunyai balita stunting dikumpulkan dan } \\
\text { diberikan edukasi yang berbeda setiap minggunya. Materi diberikan } \\
\text { dalam bentuk modul yang dibagikan ke peserta pengabdian masyarakat. } \\
\text { Edukasi diberikan dengan metode ceramah, diskusi, demonstrasi, } \\
\text { redemonstrasi dan role play. }\end{array}$ \\
\hline Koor & Pada tahap ini, tim melakukan audiensi dengan Puskesmas Jetis Kota \\
\hline inter & $\begin{array}{l}\text { Yogyakarta terkait pelaksanaan kegiatan PIBM dan berkoordinasi terkait } \\
\text { pendampingan dari puskesmas }\end{array}$ \\
\hline Evaluasi & $\begin{array}{l}\text { Pada tahap ini dilakukan evaluasi kegiatan yang telah dilakukan di } \\
\text { Kelurahan Bumijo. Evaluasi dilakukan pada minggu ke-5 kegiatan } \\
\text { PIBM. Evaluasi melibatkan pihak Kelurahan Bunijo, Puskesmas Jetis } \\
\text { dan RW } 09 \text { Keluarahan Bumijo. }\end{array}$ \\
\hline
\end{tabular}

Teknik pengumpulan data dengan cara memberian kuesioner mengenai pengetahuan gizi ibu yang dilakukan sebelum kegiatan edukasi (pre-test) dan setelah selesai 5 minggu kegiatan (post-test). Data yang telah dikumpulkan kemudian diolah dengan menggunakan software olah data SPSS. Media edukasi yang diberikan ke Ibu balita adalah berupa modul yang berisi tentang gizi balita, stunting, dan perilaku pemenuhan gizi. Pada saat pelaksanaan, strategi pembelajaran yang dilakukan adalah ceramah, diskusi, role play, demonstrasi dan redemonstrasi. Lokasi kegiatan edukasi adalah di balai warga dimana setiap pertemuan berdurasi 2 jam.

\section{HASIL DAN PEMBAHASAN}

Kegiatan pengabdian masyarakat dilakukan daerah urban yaitu di RW 09 Kelurahan Bumijo Kecamatan Jetis Kota Yogyakarta. Kelurahan Bumijo merupakan wilayah padat penduduk Kegiatan ini berhasil membentuk kelompok ibu yang tergabung pada Pendidikan Ibu Berbasis Masyarakat (PIBM). Konsep PIBM adalah kegiatan pendidikan yang terstruktur setiap minggu sekali dengan materi edukasi terdiri dari status gizi, stunting, dan perilaku pemenuhan gizi. Pertemuan dilaksanakan sesuai dengan permintaan warga yaitu setiap hari jum'at jam 15.30 - 17.00 WIB. Setiap kali kegiatan, tim menyebarkan undangan baik secara tertulis maupun melalui media seperti aplikasi whatsapp.

\section{Karakteristik Peserta}

Peserta adalah ibu-ibu yang memiliki balita stunting maupun resiko stunting. Jumlah Ibu yang rutin mengikuti kegiatan pengabdian masyarakat selama 5 minggu berjumlah 15 orang ibu balita. Karakteristik dari 15 ibu balita seperti terlihat pada Tabel 2. 
Tabel 2. Distribusi frekuensi karakteristik responden ( $\mathrm{n}=15)$

\begin{tabular}{lcc}
\hline \multicolumn{1}{c}{ Karateristik } & F & Prosentase \\
\hline Tingkat pendidikan & & \\
SD & 1 & 5,90 \\
SMP & 4 & 23,50 \\
SMA & 8 & 47,10 \\
PT & 4 & 23,50 \\
Pendapatan & & \\
Kurang & 4 & 23,5 \\
Cukup & 7 & 41,2 \\
Lebih & 6 & 35,3 \\
Usia ibu (tahun) & & \\
Min-Maks & & $20-45$ \\
Mean \pm SD & \multicolumn{2}{c}{$32,97 \pm 6,65$} \\
\hline
\end{tabular}

Berdasarkan Tabel 2 terlihat sebagian besar pendidikan responden adalah SMA dengan pendapatan cukup dan rerata usia berada pada usia produktif yaitu 32,97 tahun.

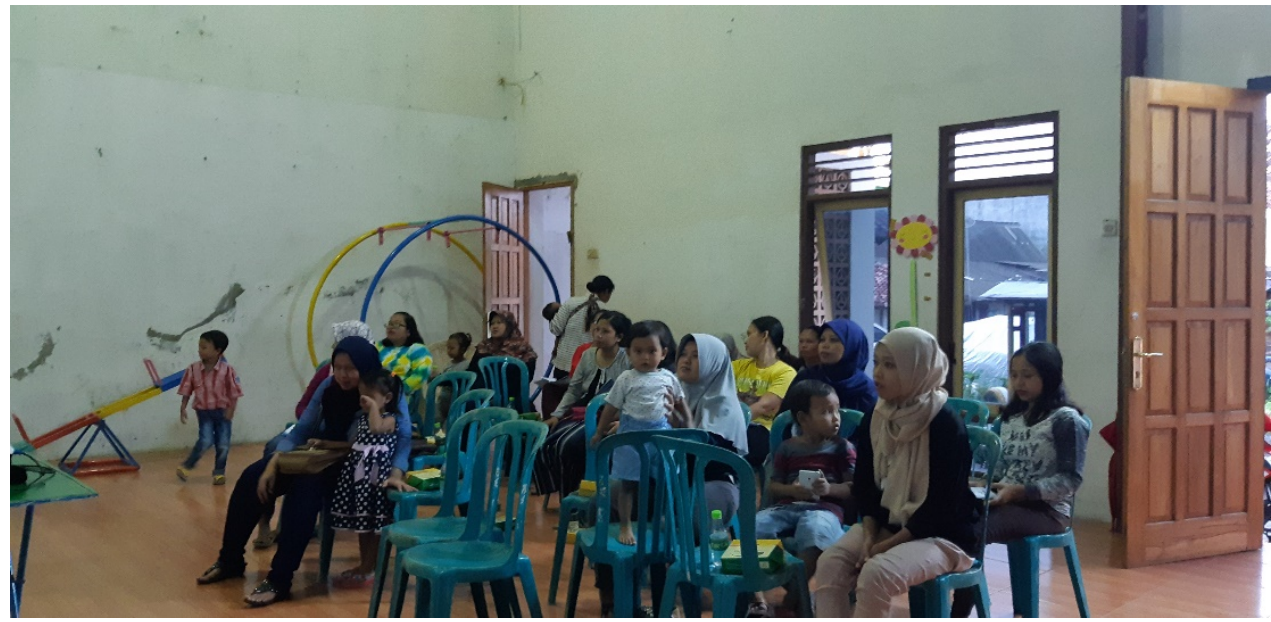

Gambar 1. Peserta kegiatan pendidikan ibu berbasis masyarakat

Tingkat pendidikan peserta kegiatan PIBM ini sebagian besar SMA, hal ini sesuai dengan data pendidikan terakhir terbanyak penduduk Provinsi DIY yang didominasi lulusan SMA. Pendidikan berkaitan dengan kemampuan untuk bertindak yang berkaitan dengan daya pikir, semakin tinggi tingkat pendidikan seseorang maka semakin luas ilmu pengetahuan sehingga menimbulkan cara pikir yang lebih baik (Damayanti et al., 2016). Banyak penelitian yang telah menyimpulkan bahwa tingkat pendidikan ibu sangat berkaitan dengan kejadian stunting pada balita. Orang tua dengan tingkat pendidikan yang baik cenderung mempunyai pengetahuan dan kemampuan untuk mengimplementasikan praktek pemberian nutrisi pada anaknya. Ibu yang mempunyai tingkat pendidikan yang tinggi mempunyai kesempatan untuk mengakses informasi yang berkaitan dengan nutrisi dan kesehatan dengan lebih baik (Handayani et al., 2017).

Penghasilan keluarga merupakan sumber pendapatan dalam memenuhi kebutuhan status gizi khususnya pada balita, dengan penghasilan yang tinggi berarti memberikan 
peluang keluarga untuk memenuhi kebutuhan pangan dengan kuantitas dan kualitas yang lebih baik sehingga kebutuhan gizi keluarga terpenuhi. Budiastutik \& Nugraheni (2019) dalam penelitiannya menunjukkan bahwa status ekonomi rumah tangga yang rendah dapat menjadi faktor resiko kejadian stunting karena tidak dapat memenuhi kebutuhan gizi keluarga. Penelitian oleh Wicaksono \& Harsanti (2020) menyatakan bahwa penghasilan keluarga yang rendah akan mempengaruhi status gizi anak melalui asupan makanan yang tidak mencukupi, peningkatan paparan terhadap infeksi, dan kurangnya perawatan kesehatan dasar.

Menurut badan pusat ststistik Yogyakarta pada tahun 2019 Kelompok usia produktif merupakan populasi penduduk dominan wilayah Provinsi Daerah Istimewa Yogyakarta. Populasi umur dewasa muda (26 - 35 tahun) menunjukkan seseorang telah memiliki tingkat kematangan dalam segi pemikiran, mampu memecahkan masalah dengan cukup baik, serta menunjukkan kematangan secara emosional maupun tindakan. Selain itu pada usia dewasa muda, seseorang sedang aktif mencari informasi dari berbagai sumber terkait suatu hal sehingga dapat menerapkan pengetahuannya dalam tatanan rumah tangga agar mencegah terjadinya stunting (Damayanti et al., 2016). Pada kegiatan pengabdian masyarakat ini minimal usia ibu adalah 20 tahun dan maksimal 45 tahun. Usia ibu merupakan faktor yang signifikan dalam kejadian stunting pada balita. Pada Ibu dengan usia kurang dari 24 tahun, mereka tidak siap dalam memberikan asuhan kepada balita, sedangkan usia lebih dari 35 tahun beresiko tinggi melahirkan anak dengan berat badan lahir rendah (Handayani et al., 2017).

\section{Pengetahuan dan sikap ibu balita}

Luaran yang diukur dari kegiatan pengabdian masyarakat ini adalah peningkatan pengetahuan dan sikap ibu balita stunting dalam memenuhi kebutuhan gizi balitanya. Cara pengukuran adalah dengan memberikan kuesioner pre-test dan post-test kegiatan. Pre-test diberikan pada minggu pertama dan post-test diberikan pada minggu ke-lima.

Tabel 3. Pengaruh PIBM terhadap pengetahuan dan sikap ibu balita $(n=15)$

\begin{tabular}{lccccc}
\hline \multicolumn{1}{c}{$\begin{array}{c}\text { Pengetahuan dan } \\
\text { Sikap }\end{array}$} & Febelum Kegiatan PIBM & \multicolumn{2}{c}{$\begin{array}{c}\text { Setelah Kegiatan } \\
\text { PIBM }\end{array}$} & P Value \\
& F & $\%$ & F & $\%$ & \\
\hline Pengetahuan & 3 & 17,6 & 6 & 35,3 & 0,608 \\
Kurang & 10 & 58,8 & 6 & 35,3 & \\
Baik & 4 & 23,5 & 5 & 29,4 & \\
Sangat baik & & & & & 0,001 \\
Sikap & 12 & 70,6 & 10 & 58,8 & \\
Baik & 5 & 29,4 & 7 & 41,2 & \\
Sangat baik & & & & & \\
\hline
\end{tabular}

(Sumber: Data Primer) 
Hasil pengabdian masyarakat terlihat bahwa pengetahuan ibu balita tidak mengalami peningkatan yang berarti sebelum dan setelah kegiatan PIBM, namun peningkatan signifikan terlihat pada sikap ibu dalam pemenuhan gizi balita stunting. Hasil pengetahuan setelah diberikan PIBM masih terdapat 35,3\% ibu memiliki pengetahuan kurang. Pengetahuan ibu atau pengasuh terkait stunting memberikan efek yang signifikan terhadap keakuratan dan ketidakakuratan paparan informasi yang mereka dapatkan (Haines \& Al., 2018).

Pengetahuan adalah sesuatu yang didapatkan dari hasil belajar seperti mengamati, menerima, dan menerapkan sehingga dari yang awalnya tidak tahu menjadi tahu. Pada kegiatan PIBM, pengetahuan ibu balita sudah cukup baik sebelum dilakukan kegiatan pengbdian masyarakat. Hal ini dipengaruhi oleh kemudahan masyarakat dalam mengakses informasi terkait stunting dimana stunting saat ini sedang menjadi issue yang digembar gemborkan oleh pemerintah. Media edukasi tentang stunting sangat mudah di akses baik dari media televisi, media online maupun media lainnya.

Pengetahuan tidak hanya didapatkan melalui pendidikan formal, rasa ingin tahu yang tinggi pada ibu dalam mendapatkan informasi tentang gizi dapat mempengaruhi pengetahuan gizi ibu. Pengetahuan yang cukup mengenai nutrisi harus dapat diaplikasikan secara terus menerus dalam kehidupan sehari-hari, sehingga diseimbangkan dengan kedisiplinan ibu dalam menjalani suatu perilaku yang baru didapatkan.

\section{Pembentukan Pendidikan Ibu Berbasis Masyarakat (PIBM)}

Kegiatan pengabdian ini berhasil memberdayakan masyarakat dengan membentuk kelompok ibu balita yang tergabung dalam Kegiatan Pendidikan Ibu Berbasis Masyarakat.

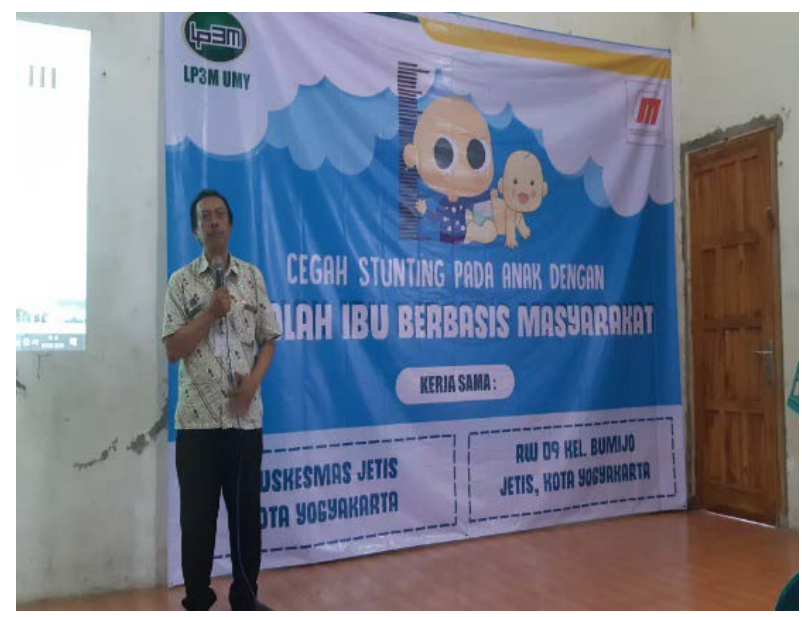

Gambar 2. Sambutan dari Lurah Bumijo

Kecamatan Jetis Yogyakarta

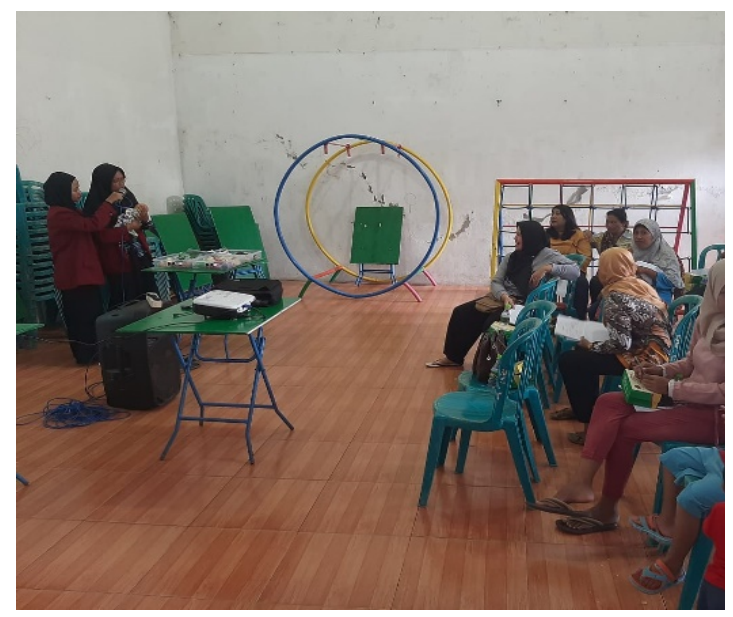

Gambar 3. Praktek teknik menyusui 

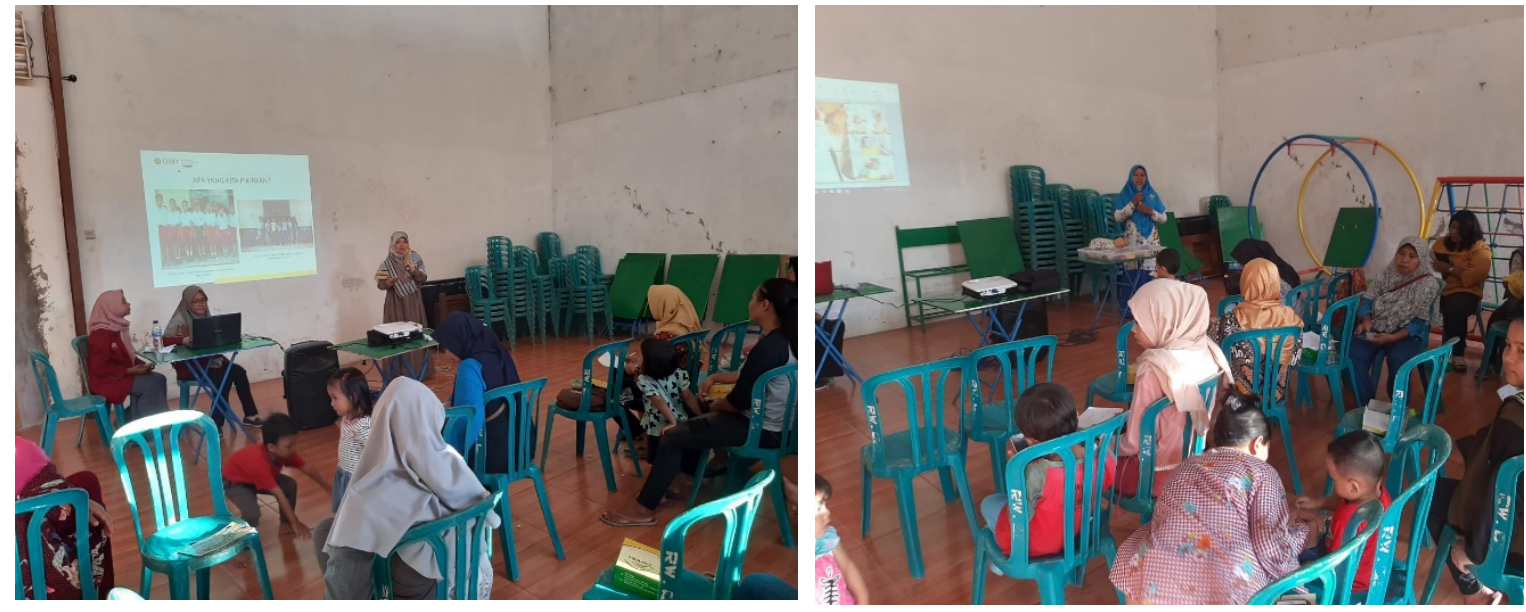

Gambar 4. Kegiatan edukasi kepada mitra

Kegiatan Pendidikan Ibu Berbasis Masyarakat (PIBM) merupakan salahsatu kegiatan promosi kesehatan. Model promosi kesehatan yang biasanya dilakukan untuk meningkatkan gizi balita meliputi tiga komponen yaitu meningkatkan asupan nutrisi (termasuk ASI eksklusif, pemberian MPASI yang sesuai, dan pemberian suplemen), meningkatkan kesehatan dan pelayanan sanitasi dan yang ketiga adalah meningkatkan stimulasi dan memonitor tumbuh kembang anak (Liang et al., 2018). Kegiatan PIBM dilakukan secara rutin setiap minggu dengan beberapa materi yaitu gizi balita, ASI eksklusif, PHBS dan monitoring tumbuh kembang balita setiap minggunya.

Pendidikan pada ibu merupakan salah satu kegiatan pendidikan kesehatan atau upaya yang dilakukan untuk mengubah perilaku baik individu maupun keluarga atau masyarakat dalam meningkatkan status kesehatan terkait Peningkatan Gizi pada Balita Stunting untuk meningkatkan pengetahuan ibu. Academic Nutrition and Dietetics (AND) memberikan definisi terkait pendidikan status gizi yaitu suatu program formal yang dilakukan untuk melatih dan meningkatkan pengetahuan keluarga dalam menentukan makanan yang bergizi, dan perilaku seseorang dalam memelihara dan memperbaiki derajat kesehatan (Dewi \& Aminah, 2016).

Pendidikan kesehatan terkait gizi merupakan salah satu rekomendasi Unicef Indonesia untuk menangani masalah balita pendek. Tingkat pendidikan ibu akan berkaitan dengan erat dengan pengetahuan mengenai status gizi sehingga dapat meningkatkan status gizi keluarga terutama balita. Ibu berperan sangat penting dalam pertumbuhan anak karena ibu yang mengasuh dan mengatur semua asupan nutrisi anak dan jika ibu sudah mengetahui tentang status gizi maka ibu akan memenuhi sumber gizi dan variasi makanan yang baik untuk dikonsumsi.

Pada kegiatan pengabdian masyarakat ini menggunakan metode pendidikan ibu berbasis masyarakat, dikarenakan ibu adalah pengasuh utama anak yang selalu menjaga, merawat, dan mengatur semua asupan nutrisi anak maka dari itu pengetahuan ibu terkait status gizi anak sangat diperlukan. Pengetahuan ibu yang baik akan membentuk perilaku yang baik dalam mengasuh dan mengelola asupan nutrisi yang dapat menyebabkan status gizi balita baik, jika pengetahuan ibu rendah maka dapat menyebabkan status gizi balita buruk. 
Keunggulan dari kegiatan Pendidikan Ibu Berbasis Masyarakat adalah terdapat kegiatan dan materi yang terstruktur dengan baik dan dilakukan secara rutin sehingga pengetahuan yang diberikan bisa secara holistic diberikan. Kegiatan ini belum pernah dilaksanakan sebelumnya baik di wilayah pengabdian maupun wilayah lainnya. Pendisikan tidak hanya diberikan dengan metode ceramah dan tanya jawab tapi juga diberikan dengan metode praktik yaitu demonstrasi dan redemonstrasi.

Kelemahan dari kegiatan Pendidikan Ibu Berbasis Masyarakat adalah sulitnya mempertahankan kegiatan atau kontinuitas dari kegiatan setelah pengabdian masyarakat selesai dikarenakan tim pengabdian masyarakat belum melatih kader untuk melanjutkan kegiatan tersebut. Pendampingan dari pihak puskesmas juga masih sangat minim dikarenakan kegiatan di puskesmas sendiri masih sangat padat sehingga kegiatan kemungkinan hanya bisa dilanjutkan dengan kegiatan dilakukan rutin setiap bulan.

\section{KESIMPULAN}

Kegiatan pengabdian masyarakat ini berhasil membentuk kegiatan Pendidikan Ibu Berbasis Masyarakat (PIBM) yang merupakan upaya peningkatan perilaku ibu dalam pemenuhan gizi balita stunting. Manfaat yang dirasakan oleh masyarakat terutama pada ibuibu yang memiliki balita stunting adalah peningkatan pengetahuan dan sikap mereka terkait bagaimana pemenuhan kebutuhan gizi balita sehingga status gizi balita dapat diperbaiki. Tantangan ke depan adalah terkait keberlanjutan program, dimana tim pengabdian masyarakat harus melatih kader agar mempunyai kemampuan dalam memberikan edukasi kepada ibu balita. Rekomendasi dari kegiatan pendampingan pada masyarakat ini adalah adanya tindak lanjut dari pihak puskesmas agar kegiatan PIBM ini dapat tetap berlanjut dengan baik dan tidak hanya kepada ibu balita yang mempunyai balita stunting tapi pada seluruh ibu balita yang memiliki anak dengan gizi kurang.

\section{UCAPAN TERIMA KASIH}

Kami ucapkan terima kasih kepada LP3M UMY selaku pemberi dana kegiatan pengabdian masyarakat. Ucapan terima kasih juga kami sampaikan kepada Lurah dan staf Kelurahan Bumijo, Puskesmas Jetis Yogyakarta dan warga RW 09 Bumijo atas bantuan dan kerjasamanya yang sangat baik.

\section{DAFTAR PUSTAKA}

Andriani, W., Rezal, F., \& Nurzalmariah. (2017). Perbedaan pengetahuan, sikap, dan motivasi ibu sesudah diberikan program mother smart grounding dalam pencegahan stunting di wilayah kerja Puskesmas Puuwatu Kota Kendari Tahun 2017. Jurnal Ilmiah Mahasiswa Kesehatan Masyarakat, 2(6).

Astuti, S., \& Megawati, G. (2018). Upaya Promotif Untuk Meningkatkan Pengetahuan Ibu Balita Tentang Pencegahan Stunting dengan Media Integrating Card di Kecamatan Jatinangor Kabupaten Sumedang.

Batiro, et. al. (2017). Determinants of stunting among children aged 6-59 months at Kindo Didaye Woreda, Wolaita Zone, Southern Ethiopia: Unmatched case control study, , 12 (12). Plos One, 12(12). https://doi.org/10.1371/journal.pone.0189106 
Beal, T., Tumilowicz, A., Sutrisna, A., Izwardy, D., \& Neufeld, L. M. (2018). A review of child stunting determinants in Indonesia. Maternal \& Child Nutrition, 14(4), 12617. https://doi.org/10.1111/mcn.12617

Budiastutik, I., \& Nugraheni, S. A. (2019). Determinant of stunting in Indonesia : A review article. International Journal of Healthcare Research, 1(2), 43-49.

Chuc, D. V., Hung, N. X., Trang, V. T., Linh, D. V., \& Khue, P. M. (2019). Nutritional Status of Children Aged 12 to 36 Months in a Rural District of Hungyen Province, Vietnam. BioMed Research International, 1-8. https://doi.org/10.1155/2019/6293184

Damayanti, R. A., Muniroh, L., \& Farapti. (2016). Perbdaan tingkat kecukupan gizi dan riwayat pemberian ASI eksklusif pada balita stunting dan non stunting. Media Gizi Indonesia, 11(1).

Dewi, M., \& Aminah, M. (2016). Pengaruh Edukasi Gizi terhadap Feeding Practice Ibu Balita Stunting Usia 6-24 Bulan (The Effect of Nutritional Knowledge on Feeding Practice of Mothers Having Stunting Toddler Aged 6-24 Months). Indonesian Journal of Human Nutrition, 3(1), 1-8. https://doi.org/10.21776/ub.ijhn.2016.003.Suplemen

Haines, A. C., \& Al., E. (2018). Analysis of rural Indonesian mothers' knowledge, attitudes, and beliefs regarding stunting. Medical Research Archives, 6(11).

Handayani, F., Siagian, A., \& Aritonang, E. Y. (2017). Mother's education as a determinant of stunting among children of age 24 to 59 months in North Sumatera Province of Indonesia. IOSR Journal Of Humanities And Social Science (IOSR-JHSS), 22(6), 5864.

Kemenkes RI. (2019). Profil Kesehatan Indonesia Tahun 2018.

Kusumaningrum, R., \& Pudjirahaju, A. (2018). Konseling Gizi Terhadap Pengetahuan Gizi Dan Sikap Ibu, Pola makan Serta tingkat Konsumsi Energi Dan Protein Balita Gizi Kurang. 4(1), 11.

Liang, W., Xing, Y., \& Pang, M. (2018). Community health education improves child health care in Rural Western China. BMC Pediatr, 18(132).

Lusita, A. P., \& Rahfiludin, M. Z. (2017). Perbedaan karakteristik balita stunting di pedesaan dan perkotaan Tahun 2017 (Studi Pada Anak Usia 24-59 Bulan di Wilayah Kerja Puskesmas. Jurnal Kesehatan Masyarakat, 5(13).

Minh Do, L., Lissner, L., \& Ascher, H. (2018). Overweight, stunting, and concurrent overweight and stunting observed over 3 years in Vietnamese children. Global Health Action, 11(1), 1517932. https://doi.org/10.1080/16549716.2018.1517932

Ngaisyah, R. D. (2017). Keterkaitan Pola Pangan Harapan (Pph) dengan Kejadian Stunting Pada Balita. Jurnal Kedokteran Dan Kesehatan, 13(1), 71-79. https://doi.org/10.24853/jkk.13.1.71-79

Pratiwi, T. D., Masrul, \& Yerizel, E. (2016). Hubungan pola asuh ibu dengan status gizi balita di wilayah kerja Puskesmas Belimbing Kota Padang. Jurnal Kesehatan Andalas, 5(3).

Rabaoarisoa, C. R., Rakotoarison, R., Rakotonirainy, N. H., Mangahasimbola, R. T., Randrianarisoa, A. B., Jambou, R., \& Randremanana, R. V. (2017). The Importance 
of Public Health, Poverty Reduction Programs and Women's Empowerment in The Reduction of Child Stunting in Rural Areas of Moramanga and Morondava, Madagascar. Plos One, 12(10). https://doi.org/10.1371/journal.pone.0186493

Rahmawati, V. E., Pamungkasari, E. P., \& Murti, B. (2018). Determinants of Stunting and Child Development in Jombang District. Journal of Maternal and Child Health, 3(1), 68-80.

Sahanggamu, P. D., Purnomosari, L., \& Dillon, D. (2017). Information exposure and growth monitoring favour child nutrition in rural Indonesia. Asia Pacific Journal of Clinical Nutrition, 26(2), 313-316. https://doi.org/10.6133/apjcn.012016.09

Saputri, R. M. (2018). Status gizi dan riwayat asi ekslusif dengan kejadian stunting. Jurnal Kesehatan STIKES Darul Azhar Batulicin, 6(1).

Torlesse, H., Cronin, A. A., Sebayang, S. K., \& Nandy, R. (2016). Determinants of Stunting in Indonesian Children: Evidence from a Cross-Sectional Survey Indicate a Prominent Role for the Water, Sanitation and Hygiene Sector in Stunting Reduction. BMC Public Health, 16(1), 669. https://doi.org/10.1186/s12889-016-3339-8

Wicaksono, F., \& Harsanti, T. (2020). Determinants of stunted children in Indonesia: a multilevelanalysis at the individual, household, and community levels. Kesmas: National Public Health Journal, 15(1), 48-53. 